\title{
Scenario analysis of fluoride contamination in the groundwater in
} Kerala.

\section{Análisis de escenarios de contaminación por fluoruro en el agua subterránea en Kerala}

\author{
Sahila Beegum ${ }^{1}$, Saranya Jeyalakshmi² \\ ${ }^{1}$ University of Nebraska-Lincoln, Lincoln, NE 68588-6105, United States, \\ beegumsahila@gmail.com \\ 2University of Windsor, Windsor, Ontario N9B 3P4, Canada, saranyaj55@gmail.com
}

\begin{abstract}
The Kerala State is a narrow strip of land in the southwest of India, with the Arabian Sea on the west and the Western Ghats in the east. Recent studies related to contaminant transport in the soil and groundwater in Kerala have reported Fluoride contamination in the aquifers. Due to the poor quality of the surface water sources in the state, the majority of the population in the state depends on groundwater resources for domestic and agricultural uses. When using groundwater for domestic purposes, it is highly important to analyze the quality of the groundwater. This study focuses on the analysis of the Fluoride transport in the soil and groundwater in two different lithological units (laterite and coastal alluvium) in the State. The study concluded that the aquifer in coastal alluvium formation is more susceptible to Fluoride contamination compared to the laterite formation.
\end{abstract}

Keywords- Groundwater contamination, dispersion, diffusion, HYDRUS-1D

\section{INTRODUCTION}

Kerala state has two main lithological units. They are the (a) laterites and (b) coastal alluvium. The most widely distributed lithological unit in the state is laterite. The thickness of laterite formation varies from a few meters to about $30 \mathrm{~m}$. The depth to the water level in the formation ranges from less than a meter to $25 \mathrm{~m}$ below ground level. The yield from the laterite aquifer formation varies from 0.5 to $6 \mathrm{~m}^{3}$ per day. The coastal alluvium formation is found majorly 
Sustainability, Agri, Food and Environmental Research, (ISSN: 0719-3726), 10(X), 2022:

http://dx.doi.org/

along the coastal plains of the state. The thickness of this formation varies from a few meters to $100 \mathrm{~m}$. The depth to water level ranges from less than a meter to $6 \mathrm{~m}$ below ground level (http://www.kerenvis.nic.in). Several recent studies have reported Fluoride content in the soil and groundwater at different locations in these lithological units (Raj et al.,2017; Shaji et al., 2007; Shaji et al., 2018). The majority of the state population depends on groundwater for domestic and agricultural purposes. In this context, it is important to analyze the transfer and transformation of Fluoride in the soil and groundwater.

The objective of the study is to carry out a scenario analysis for the transport of Fluoride in the soil and groundwater for the two main lithological units in the state. These units are considered as Case 1 and Case 2 in this study; Case 1: Fluoride transport in laterite formation for an average groundwater depth at $25 \mathrm{~m}$, Case 2: Fluoride transport in coastal alluvium for an average groundwater depth of $6 \mathrm{~m}$. Simulations are carried out using the HYDRUS-1D modeling tool (Šimůnek et al., 2016).

\section{MATERIALS AND METHODS}

The HYDRUS-1D model used to carry out the scenario analysis simulates water flow in the unsaturated zone using the modified one-dimensional Richards equation:

$$
\frac{\partial \theta}{\partial t}=\frac{\partial}{\partial z}\left[K(h) \frac{\partial h}{\partial z}-K(h)\right]-S
$$

where $\theta$ is the volumetric water content (dimensionless), $h$ is the soil water pressure head $[L]$, $\mathrm{t}$ is time $[\mathrm{T}], \mathrm{z}$ is the vertical coordinate $[\mathrm{L}], \mathrm{S}$ is the sink term $\left[\mathrm{T}^{-1}\right]$, and $\mathrm{K}(\mathrm{h})$ is the unsaturated hydraulic conductivity $\left[\mathrm{LT}^{-1}\right]$. The unsaturated hydraulic conductivity, $\mathrm{K}(\mathrm{h})$, and the water content, $\theta(h)$, depends on the soil water pressure head.

The physicochemical properties of the two formations are given in Table 1 (Dhanya et al., 2016). The van Genuchten-Mualem analytical model (van Genuchten, 1980) was used to describe the soil hydraulic properties of the formations with the parameters given in Table 2. These parameters were obtained using the neural network prediction of soil hydraulic properties using the Rosetta Lite V.1.1 (Schaap et al., 2001).

Table 1. Physicochemical properties of the soils

\begin{tabular}{|c|c|c|}
\hline \multicolumn{3}{|c|}{ Physicochemical properties of the soils } \\
\hline & Laterite soil & Coastal alluvium \\
Property & soil \\
\hline
\end{tabular}


Sustainability, Agri, Food and Environmental Research, (ISSN: 0719-3726), 10(X), 2022: http://dx.doi.org/

\begin{tabular}{|c|c|c|}
\hline Texture & Sandy loam & Loamy sand \\
\hline Fine sand (\%) & 13.27 & 20.21 \\
\hline $\begin{array}{c}\text { Coarse sand } \\
(\%)\end{array}$ & 47.98 & 60.47 \\
\hline Silt (\%) & 27.2 & 8.48 \\
\hline Clay (\%) & 11.56 & 10.84 \\
\hline Density (g/cc) & 1.77 & 1.37 \\
\hline
\end{tabular}

Details of the simulation settings are given in Table 3. The soil profiles are divided into 100 finite elements for Case 1 and Case 2. The surface boundary condition is given at the atmospheric boundary condition with surface runoff (for water flow), concentration flux (for solute transport) and the bottom boundary condition is given as free drainage (for water flow) and zero concentration gradient (for solute transport).

Table 2. van Genuchten-Maulem analytical model parameters

\begin{tabular}{|l|l|l|}
\hline $\begin{array}{l}\text { van Genuchten-Maulem analytical } \\
\text { model parameters }\end{array}$ & Laterite soil & $\begin{array}{l}\text { Coastal alluvium } \\
\text { soil }\end{array}$ \\
\hline Residual water content, $\theta_{r}$ & 0.078 & 0.05 \\
\hline Saturated water content, $\theta_{\mathrm{s}}$ & 0.433 & 0.43 \\
\hline $\begin{array}{l}\text { Saturated hydraulic conductivity, } \\
\mathrm{K}_{\mathrm{s}} \mathrm{cm} / \text { day }\end{array}$ & 24.96 & 144.28 \\
\hline Pore connectivity parameter, I(-) & 0.5 & 0.5 \\
\hline Shape parameters, a (1/cm/), $\mathrm{n(-)}$ & $0.036,1.56$ & $0.0322,1.7131$ \\
\hline
\end{tabular}

Table 3. The simulation settings in HYDRUS-1D for Case 1 and Case 2.

\begin{tabular}{|c|c|c|}
\hline Details & $\begin{array}{l}\text { Case } 1 \text { : Fluoride transport in } \\
\text { laterite formation }\end{array}$ & $\begin{array}{l}\text { Case } 2 \text { : Fluoride transport in } \\
\text { coastal alluvium }\end{array}$ \\
\hline Depth of HYDRUS-1D column & $25 \mathrm{~m}$ & $6 \mathrm{~m}$ \\
\hline Duration of the simulation & 100 days & 100 days \\
\hline 5 observation points & $\begin{array}{l}\mathrm{N} 1=0 \mathrm{~cm}, \mathrm{~N} 2=120 \mathrm{~cm}, \\
\mathrm{~N} 2=240 \mathrm{~cm}, \mathrm{~N} 3=360 \mathrm{~cm}, \\
\mathrm{~N} 4=480 \mathrm{~cm} \text { and } \mathrm{N} 5=600 \mathrm{~cm}\end{array}$ & $\begin{array}{l}\mathrm{N} 1=0 \mathrm{~cm}, \mathrm{~N} 2=120 \mathrm{~cm}, \\
\mathrm{~N} 2=240 \mathrm{~cm}, \mathrm{~N} 3=360 \mathrm{~cm}, \\
\mathrm{~N} 4=480 \mathrm{~cm} \text { and } \mathrm{N} 5=600 \mathrm{~cm}\end{array}$ \\
\hline
\end{tabular}


Sustainability, Agri, Food and Environmental Research, (ISSN: 0719-3726), 10(X), 2022: http://dx.doi.org/

\begin{tabular}{|c|c|c|}
\hline 5 observation time & $\begin{array}{l}\mathrm{T} 0=0 \text { day, } \mathrm{T} 1=20 \text { day, } \\
\mathrm{T} 2=40 \text { day, } \mathrm{T} 3=60 \text { day, } \\
\mathrm{T} 4=80 \text { day, and } \mathrm{T} 5=100 \text { day }\end{array}$ & $\begin{array}{l}\mathrm{T} 0=0 \text { day, } \mathrm{T} 1=20 \text { day, } \\
\mathrm{T} 2=40 \text { day, } \mathrm{T} 3=60 \text { day, } \\
\mathrm{T} 4=80 \text { day, and } \mathrm{T} 5=100 \text { day }\end{array}$ \\
\hline Longitudinal dispersivity & $2.5 \mathrm{~m}$ & $0.6 \mathrm{~m}$ \\
\hline $\begin{array}{l}\text { Molecular diffusion } \\
\text { coefficient in free water }\end{array}$ & $1.27 \mathrm{~cm}^{2} /$ day & $1.75 \mathrm{~cm}^{2} /$ day \\
\hline $\begin{array}{l}\text { Initial pressure head } \\
\text { distribution in the soil }\end{array}$ & $\begin{array}{l}\text { Pressure head varies from } 0 \\
\mathrm{~m} \text { at the bottom to }-25 \mathrm{~m} \text { at } \\
\text { the surface }\end{array}$ & $\begin{array}{l}\text { Pressure head varies from } 0 \\
\mathrm{~m} \text { at the bottom to }-6 \mathrm{~m} \text { at } \\
\text { the surface }\end{array}$ \\
\hline $\begin{array}{l}\text { Concentration flux at the } \\
\text { surface }\end{array}$ & $1 \mathrm{mg} / \mathrm{l}$ & $1 \mathrm{mg} / \mathrm{l}$ \\
\hline
\end{tabular}

\section{RESULTS AND DISCUSSIONS}

Fig. 1 shows the variation of concentration of Fluoride in the laterite soil (Case 1 ) with time at five observation nodes in the soil domain $(\mathrm{N} 1=0 \mathrm{~cm}, \mathrm{~N} 2=120 \mathrm{~cm}, \mathrm{~N} 2=240 \mathrm{~cm}, \mathrm{~N} 3=360 \mathrm{~cm}$, $\mathrm{N} 4=480 \mathrm{~cm}$, and $\mathrm{N} 5=600 \mathrm{~cm}$ ) (a), concentration profile at different time steps ( $\mathrm{T} 0=0$ day, $\mathrm{T} 1=20$ day, $\mathrm{T} 2=40$ day, $\mathrm{T} 3=60$ day, $\mathrm{T} 4=80$ day and $\mathrm{T} 5=100$ day) (c), Cumulative solute flux at the bottom of the soil profile (c) and bottom solute flux (d).

Analysis of Case 1: From Fig. 1(a), it can be observed that the concentration profile is moving down with time. The Fluoride is reaching the groundwater after approximately 60 days after the start of the application of the solute at the surface. The concentration at groundwater is found to be $0.07 \mathrm{mg} / \mathrm{l}$ on the $100^{\text {th }}$ day. From Fig. 1(b), it can be observed that the concentration is increasing at all the observation points in the profile with time. At the surface (N1) the concentration has reached a maximum up to $0.97 \mathrm{mg} / \mathrm{l}$, whereas the maximum concentration reached the bottom (N5) is $0.07 \mathrm{mg} / \mathrm{l}$. From Fig. 1 (c), it can be observed that the cumulative solute flux at the bottom of the soil is $4.0 \mathrm{mg} / \mathrm{cm}^{2}$ and the maximum bottom solute flux is $0.3 \mathrm{mg} / \mathrm{cm}^{2} /$ day (Fig. 1 (d)). From Fig. $1(\mathrm{c})$ and $1(\mathrm{~d}$ ), it can be observed the Fluoride reached the groundwater 60 days after the application at the surface.

Fig. 2 shows the variation of concentration of Fluoride in the coastal alluvium soil (Case 2) with time at five observation nodes in the soil domain $(\mathrm{N} 1=0 \mathrm{~cm}, \mathrm{~N} 2=120 \mathrm{~cm}, \mathrm{~N} 2=240 \mathrm{~cm}$, $\mathrm{N} 3=360 \mathrm{~cm}, \mathrm{~N} 4=480 \mathrm{~cm}$, and $\mathrm{N} 5=600 \mathrm{~cm})(\mathrm{a})$, concentration profile at different time steps 
Sustainability, Agri, Food and Environmental Research, (ISSN: 0719-3726), 10(X), 2022: http://dx.doi.org/

( $\mathrm{T} 0=0$ day, $\mathrm{T} 1=20$ day, $\mathrm{T} 2=40$ day, $\mathrm{T} 3=60$ day, $\mathrm{T} 4=80$ day and $\mathrm{T} 5=100$ day) (c), Cumulative solute flux at the bottom of the soil profile (c) and bottom solute flux (d).

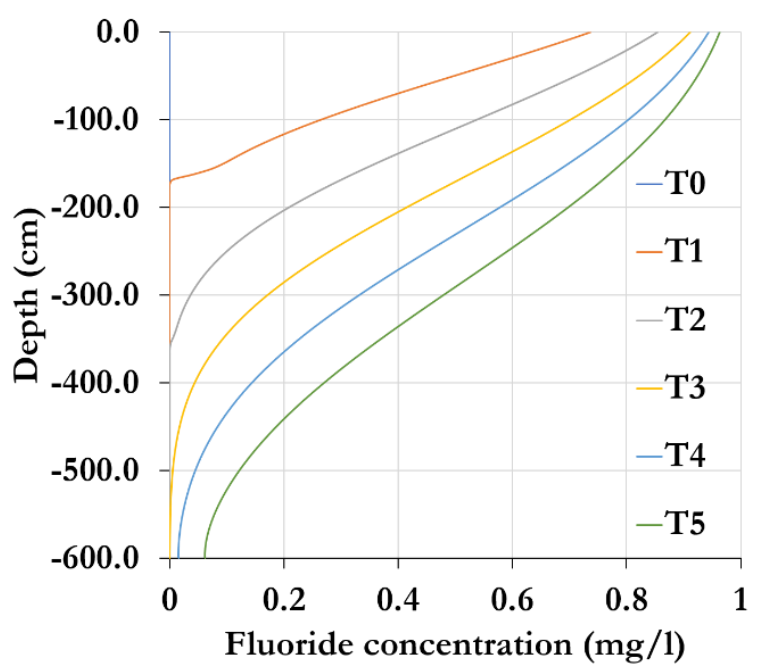

(a)

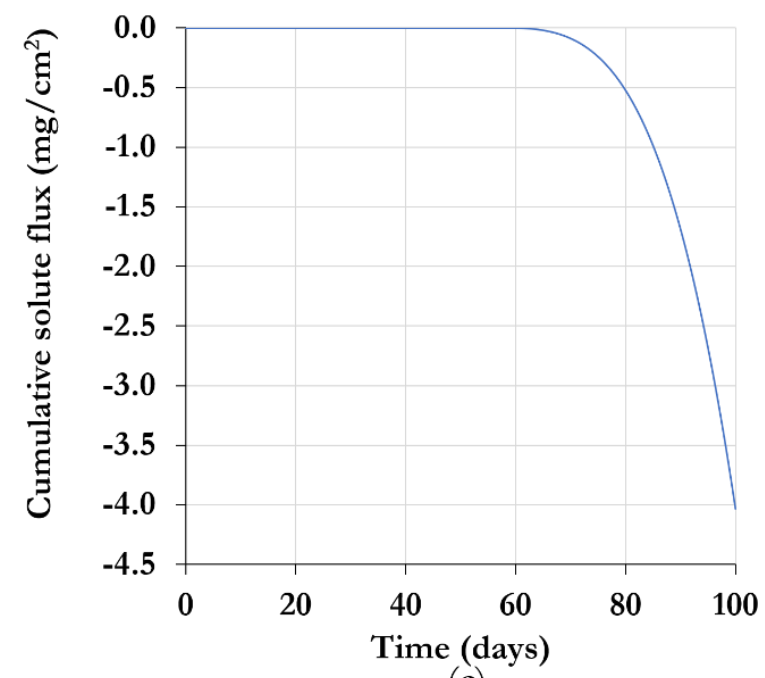

(c)

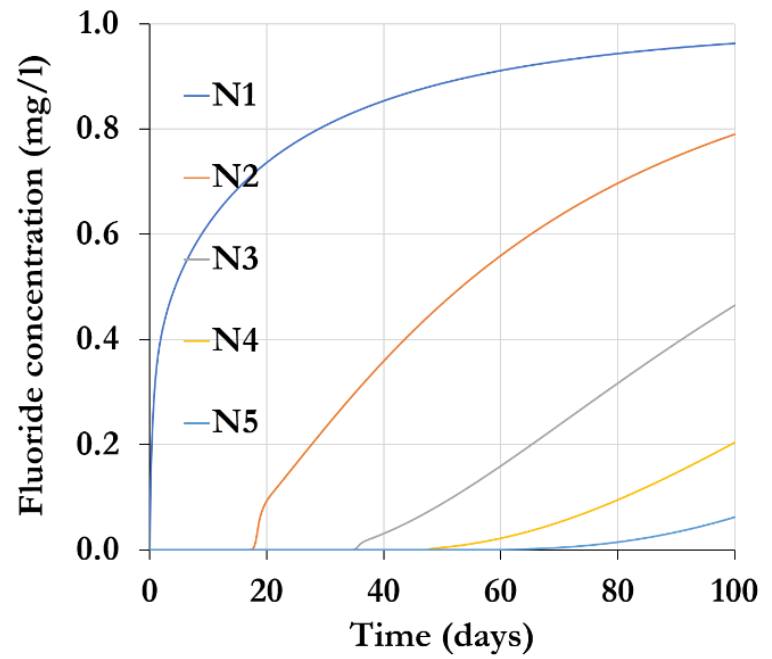

(b)

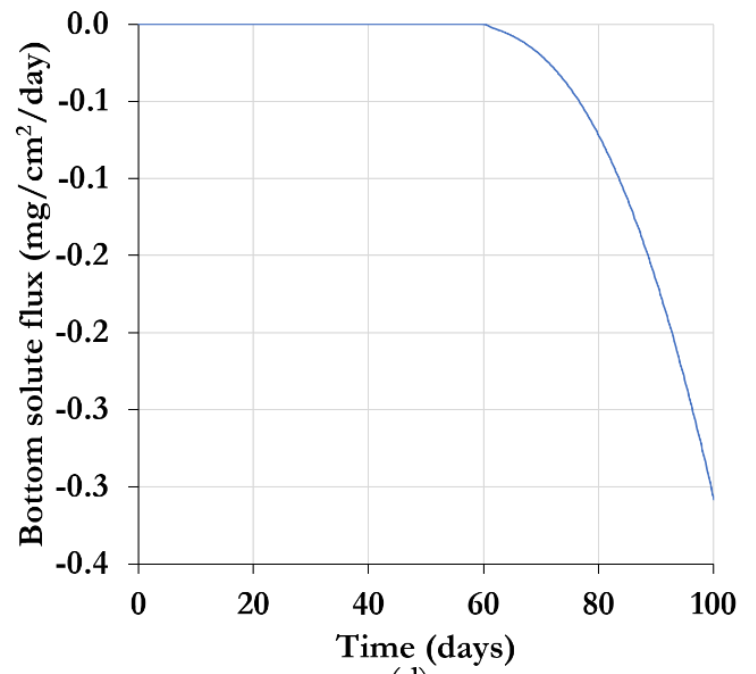

(d)

Figure 1. Variation of concentration of Fluoride in the laterite soil with time at five observation nodes in the soil domain $(\mathrm{N} 1=0 \mathrm{~cm}, \mathrm{~N} 2=120 \mathrm{~cm}, \mathrm{~N} 2=240 \mathrm{~cm}, \mathrm{~N} 3=360 \mathrm{~cm}$, $\mathrm{N} 4=480 \mathrm{~cm}$, and $\mathrm{N} 5=600 \mathrm{~cm})(\mathrm{a})$, concentration profile at different time steps ( $\mathrm{T} 0=0$ day, $\mathrm{T} 1=20$ day, $\mathrm{T} 2=40$ day, $\mathrm{T} 3=60$ day, $\mathrm{T} 4=80$ day and $\mathrm{T} 5=100$ day) (c), Cumulative solute flux at the bottom of the soil profile (c) and bottom solute flux (d). 
Sustainability, Agri, Food and Environmental Research, (ISSN: 0719-3726), 10(X), 2022: http://dx.doi.org/

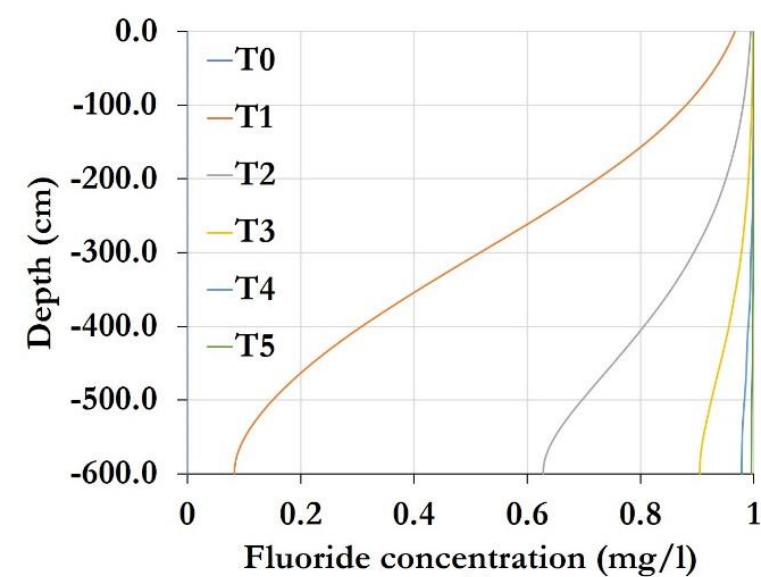

(a)

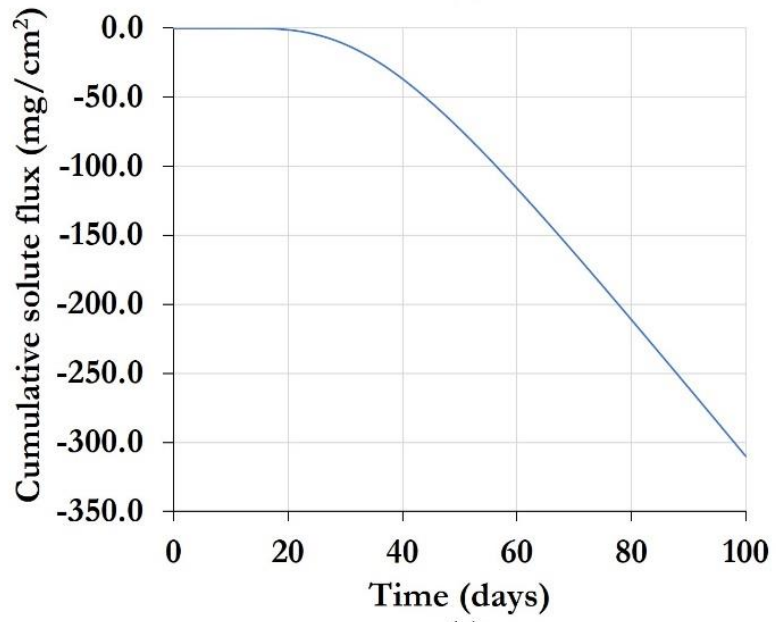

(c)

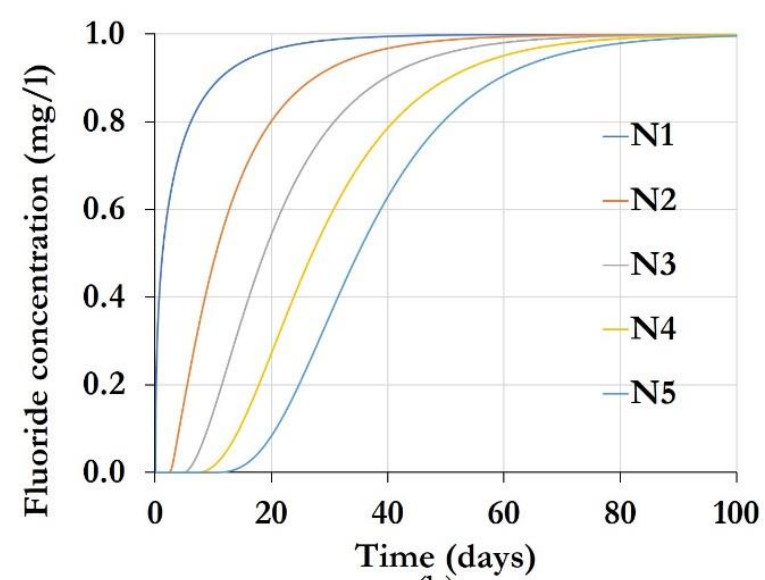

(b)

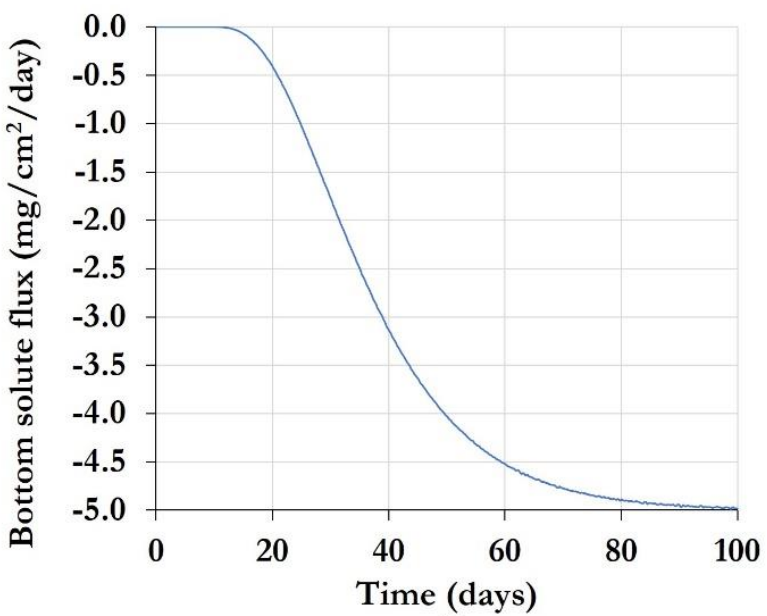

(d)

Figure 2. Variation of concentration of Fluoride in the coastal alluvium soil with time at five observation nodes in the soil domain $(\mathrm{N} 1=0 \mathrm{~cm}, \mathrm{~N} 2=120 \mathrm{~cm}, \mathrm{~N} 2=240 \mathrm{~cm}, \mathrm{~N} 3=360 \mathrm{~cm}$, $\mathrm{N} 4=480 \mathrm{~cm}$, and $\mathrm{N} 5=600 \mathrm{~cm})(\mathrm{a})$, concentration profile at different time steps $(\mathrm{TO}=0$ day, $\mathrm{T} 1=20$ day, $\mathrm{T} 2=40$ day, $\mathrm{T} 3=60$ day, $\mathrm{T} 4=80$ day and $\mathrm{T} 5=100$ day) (c), Cumulative solute flux at the bottom of the soil profile (c) and bottom solute flux (d).

Analysis of Case 2: From Fig. 2(a), it can be observed that the concentration profile is moving down with time. The Fluoride is reaching the groundwater after approximately 18 days after the start of the application of the solute at the surface. The concentration at groundwater is found to be $1 \mathrm{mg} / \mathrm{I}$ on the $100^{\text {th }}$ day, which is the same concentration applied at the surface. From Fig. 2(b), it can be observed that the concentration is increasing at all the observation points in the profile with time. At the surface (N1) the concentration has reached a maximum of $1 \mathrm{mg} / \mathrm{l}$ on the $40^{\text {th }}$ day, whereas the maximum concentration reached the bottom (N5) is 1 $\mathrm{mg} / \mathrm{l}$ at approximately 80 days. From Fig. 2 (c), it can be observed that the cumulative solute flux at the bottom of the soil is $305.0 \mathrm{mg} / \mathrm{cm}^{2}$ and the maximum bottom solute flux is 5.0 
Sustainability, Agri, Food and Environmental Research, (ISSN: 0719-3726), 10(X), 2022:

http://dx.doi.org/

mg/cm²/day (Fig. 2 (d)). From Fig. 1(c) and 1(d), it can be observed the Fluoride reached the groundwater 18 days after the application at the surface.

Comparison of Case 1 and Case 2: It can be observed that the Fluoride has reached the groundwater at a faster rate in coastal alluvium formation (Case 2) compared to laterite formation (Case 1). This is majorly due: (a) the lesser depth of water table in case of alluvium formation, (b) the larger hydraulic conductivity of alluvium formation compared to laterite soil. The maximum concentration at the groundwater for Case 2 (coastal alluvium) is $1 \mathrm{mg} / \mathrm{l}$, whereas it is reaching a maximum of only $0.07 \mathrm{mg} / \mathrm{l}$ in case of Case 1 (Laterite soil) after 100 days from the start of the Fluoride application at the surface.

Scenario analysis is carried out for investigating the Fluoride transport in two different lithological units in Kerala. It is observed from the simulation study that the coastal alluvium is more susceptible to groundwater contamination compared to Laterite formation. The larger hydraulic conductivity and the depth to the water table is the major driving factor for the transport of Fluoride in the soil. Disposing waste or wastewater containing Fluoride should be highly controlled or restricted at the coastal alluvium region of the state compared to the laterite formation. This study also highlights the modeling capability of the HYDRUS-1D model in simulating water flow and contaminant transport in soil and groundwater.

\section{REFERENCES}

Dhanya, M.S., George, T. and Kumar, S.V., 2016. Persistence of Carbosulfan Formulations in Laterite and Coastal Alluvium Soils of Kerala. Pesticide Research Journal, 28(2), pp.210214.

Raj, D. and Shaji, E., 2017. Fluoride contamination in groundwater resources of Alleppey, southern India. Geoscience Frontiers, 8(1), pp.117-124.

Schaap, M. G., Leij, F. J., Van Genuchten, M. T., \& Brown, G. E. (2001). Rosetta: a computer program for estimating soil hydraulic parameters with hierarchical pedotransfer functions. Journal of Hydrology, 251, 163-176. Retrieved from http://www.ussl.ars.usda. gov/.

Shaji, E., Gómez-Alday, J.J., Hussein, S., Deepu, T.R. and Anilkumar, Y., 2018. Salinization and deterioration of groundwater quality by nitrate and fluoride in the Chittur block, Palakkad, Kerala. Journal of the Geological Society of India, 92(3), pp.337-345. 
Sustainability, Agri, Food and Environmental Research, (ISSN: 0719-3726), 10(X), 2022:

http://dx.doi.org/

Shaji, E., Viju, J. and Thambi, D.S., 2007. High fluoride in groundwater of Palghat District, Kerala. Current Science, pp.240-245.

Šimůnek, J., van Genuchten, M. T., \& Šejna, M. 2016. Recent Developments and Applications of the HYDRUS Computer Software Packages. Vadose Zone Journal, 15(7), 25 pp., https://doi.org/10.2136/vzj2016.04.0033

van Genuchten, M.T. 1980. A closed-form equation for predicting the hydraulic conductivity of unsaturated soils. Soil Science Society of America Journal, 44(5), 892-898.

Received: 30th January 2021; Accepted: 14 ${ }^{\text {th }}$ March 2021; First distribution: 01th April 2021 